\title{
Research on Teaching Resources Sharing Mechanism of Higher Education Park
}

\author{
He Yongqiang* \\ College of Computers \\ Henan Institute of Engineering \\ Zhengzhou, China \\ e-mail: yqhe18@126.com \\ * Corresponding Author
}

\author{
Qin Qin \\ College of Computers \\ Henan Institute of Engineering \\ Zhengzhou, China \\ e-mail: qq@haue.edu.cn
}

\begin{abstract}
This paper presents the relationship between timing and level using Bayesian model for sensor network node failure prediction methods, combined with each node sensor network processing information, the use of qualitative analysis time information will be integrated into the node to analyze the fault propagation mechanism and failure prediction ; according to the probability of failure history information node and the current operating conditions, forecasts and determination nodes, using the parameters of learning and probabilistic reasoning, predict the probability of failure of the upper node. Through simulation analysis, and comparative analysis with other forecasting methods to verify the accuracy and precision of the method for sensor network node failure prediction provides new ideas and methods.
\end{abstract}

Keywords- Higher Education Park; teaching resources; sharing mechanism; resource sharing;

\section{INTRODUCTION}

Higher Education Park is that many higher education principals are concentrated in a regional. It forms many universities as the core, including various service agencies, with the function of training people and development, and a certain environmental features of the community. The formation of the Higher Education Park is closely bound up the development environment and own internal reform of our higher education.

\section{BACKGROUND OF HIGHER EDUCATION PARK}

\section{A. Massive expansion of higher education}

With the rapid development of the social, economic and cultural, our higher education goes towards universal higher education. We meet the social and personal needs by expanding the scale. The Massive expansion and universal of higher education can be achieved through various channels. For example, excavating internal resources of the university, increasing an external investment, and expanding scale by joint operation of schools etc. The way of expanding higher education by increasing the university resource utilization is limited directly by the institutions of higher education resources utilization. It has certain limitations. It is not the efficiency increases by the excesses to expand the scale, but the quality loss .According to the scale of economic theory, there are two cases the change of the school scale causes the higher education unit cost variances. One yields higher education services with the unit cost decline. The other yields higher education services with the rising unit cost The former is good the internal financial institutions. It is due to utilization of resources more efficiently and management efficiency after the massive expansion. The latter is bad the internal financial institutions. It is due to inadequate teaching resources and inconvenient management after the massive expansion of the university. As shows in Fig 1.

We expand the higher education in the size scale, at the same time we pursue the economy of scale. It focuses on the internal economic of the university, and prevents and avoids the internal not economic of the university. There is varying degrees to waste about our existing institutions of the higher education resources (such as teacher resource), Another part of resources is the serious shortage. This question requires us to try to dig and efficient use of existing institutions of higher education resources to expand the higher education. At the same time we should use the superfluous education resources to establish the branch of the university and new university. We can achieve the university expansion by this mean. At the same time we can relax some conflicts. For instance the existing campus space resources is not enough, the teacher doesn't make full use of resources, etc.

\section{B. The rapid development of local economy}

In the case of serious shortage of our education resources, the main investment should be the subject of some local governments, social groups or individuals. With the development of local economy, it is possible to run a school by some local governments, social groups or individuals. On the other hand, with the development of local economy, the rich human resources and wide range of human markets provide the adequate education resources and wide market of the product. All these create the external material conditions to establish the Higher Education Park in the focus of the resources and market.

\section{Efficiency Concept of the Higher Education}

The higher education is more and more important on social and economic development. People pay attention to the efficiency of the education. Investors and governments begin to make education as their investment objectives. Because of their investment, it makes many universities relocated, build up a new campus. In order to improve the efficiency of the university, provide convenient for the 
teaching resource sharing, and prevent the university in the new campus of the selection itself to waste the resource. The many investment, the government and the various institutions of the higher education institutions will choose the new campus, make the university in one place and to establish the community university. It facilitates the sharing of teaching resources and not teaching resources, to improve the efficiency of the education.

Figure 1. Relationship of ducation scale and cost of education

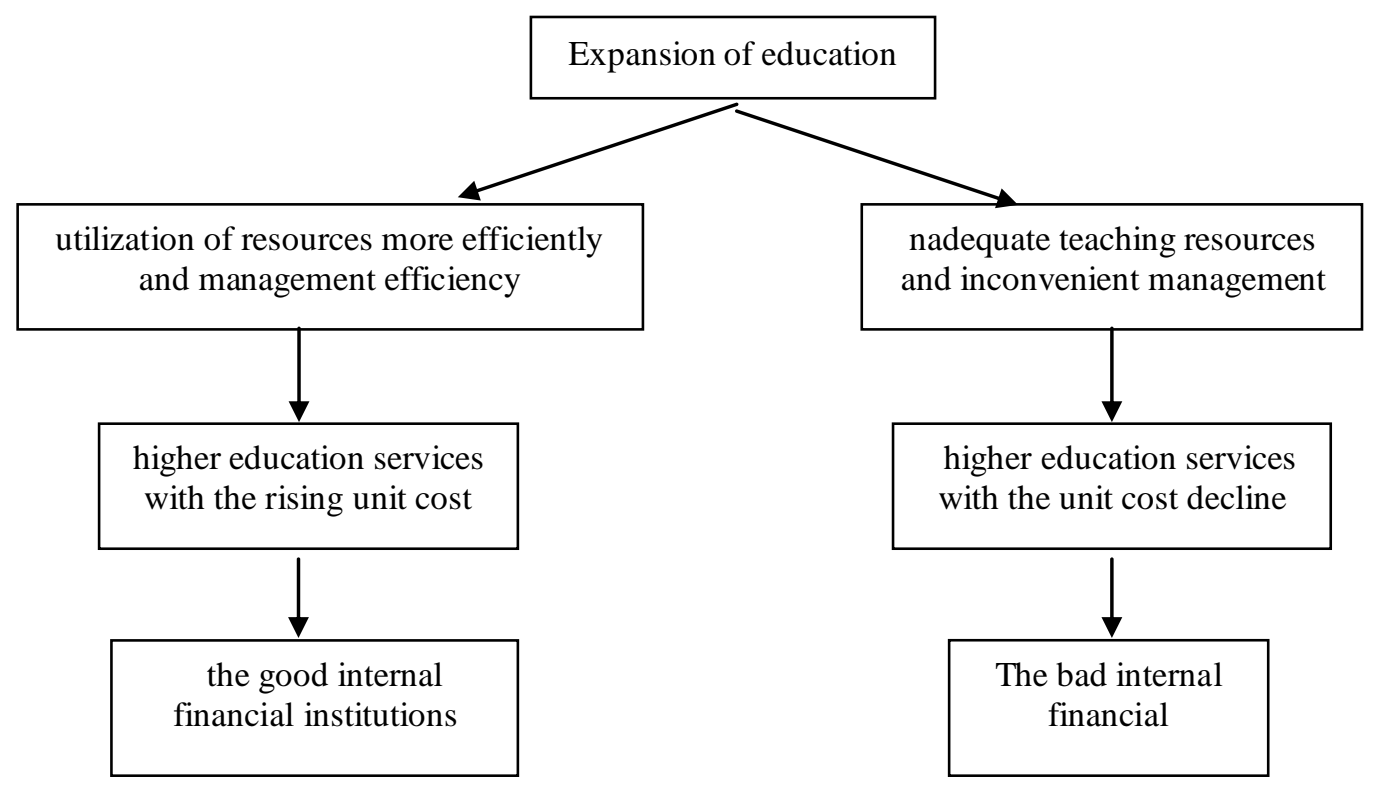

\section{Innovation and Development}

The university innovation includes not only the educational content, methods and means but also educational organizations. The establishment of the university town, will no doubt to provide more liberal environment and convenient for creating the new university and operating the new university operation. In this new environment, it is easy to use new forms and operations to run a university. It is convenient to promote the development and innovation of the higher education.

\section{E. Innovation and Development}

The university innovation includes not only the educational content, methods and means but also educational organizations. The establishment of the university town, will no doubt to provide more liberal environment and convenient for creating the new university and operating the new university operation. In this new environment, it is easy to use new forms and operations to run a university. It is convenient to promote the development and innovation of the higher education.

\section{BUILDING SHARING MECHANISM OF TEACHING RESOURCES}

From the background of the Higher Education Park, the purpose of the Higher Education Park is to increase in efficiency and quality of the school by the teaching resource sharing. Thus the scientific effective sharing is the important means to achieve this goal. The core is the mechanism and the effective operation of teaching resources sharing of Higher Education Park.

\section{A. Connotation}

Education resource is defined the total of the human resources, material resources and intangible resources for the education. The resource that supports directly various resources for the teaching activities are called teaching resources, such as teacher, teaching information, teaching practice base, etc. Non-school resources is defined the various service resources for teaching activities, such as school environment, library, the stadium, public transport, public service system, etc.

Teaching resources sharing is the process of using the educational resources together by school cooperation. Because of the indirect sexual between non-school resources and teaching activities, investment principal can keep separate from the school principal, thus non-school resources can go towards market-oriented and socialized. It can provide rights for different universities by paying for the service manner to achieve the sharing of the no teaching resources between different school principals in Higher Education Park. It is easy for the sharing of this market-oriented operation mechanism. For teaching resources with the teaching activities directly, because many resources condition each other, that makes the sharing of the teaching resources is the key and difficulty. At the same time course is the basic unit of teaching, during the teaching resources, both human resources and material resources service for teaching. Thus the course sharing is the best reflects for the sharing of the teaching resource. As shows in Fig 2.

Sharing mechanism of the teaching resources is the sharing process and form of the teaching resource. It includes the service and support for the sharing of the teaching resource, the policy-making and execution for the 
sharing of the teaching resource, and the management of the teaching resource, etc, all these how to form an efficient operation mechanism. The goal of the teaching resource sharing mechanism is to improve efficiency, the key is the course sharing. This mechanism should improve efficiency. The university should conscientiously safeguard and comply this mechanism to achieve the coexistence and win-win.

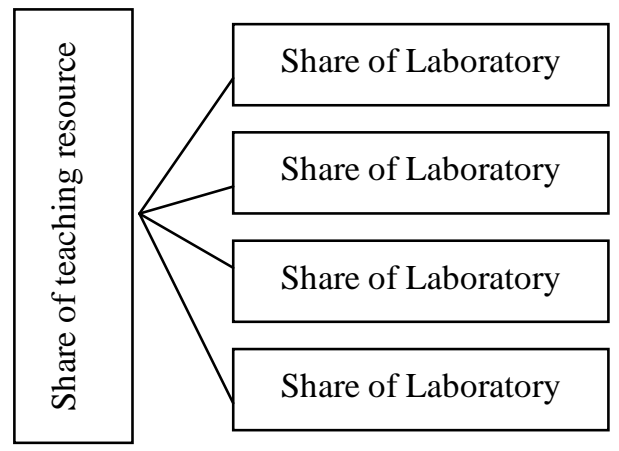

Figure 2. Share of teaching resource

\section{B. Administration}

There are different levels, different categories and every university has its different characteristics in the Higher Education Park. Every university has different advantages in the teaching resource, the subject, professional and the course merit. Although they are in one place, they fall into different sponsoring bodies. If we want to achieve the teaching resource sharing, we must establish the coordination agencies, formulate relevant policies, plan and coordinate the major issues for the teaching resource sharing between different universities. We must coordinate the operation problem to ensure the teaching resource sharing goes in an orderly way. We must solve the question during the teaching resource sharing.

So we can set University Rectors' Conference of Higher Education Park, University Provost' Conference of Higher Education Park, Teaching Steering Committee of Higher Education Park, Teaching administration of Higher Education Park. As shown in Table 1.

\section{MANAGEMENT SySTEM AND OPERATION MECHANISM}

\section{A. Establish the Study System to be Beneficial of Teaching Resource Sharing}

On the one hand academic credit may be a single or multiple resource group sharing. On the other hand it may be the course sharing. The teaching resource sharing may introduce the teaching resource, For instance we can employ other school teachers to teach, hire the teaching land, etc. The teaching resource sharing also may jointly build and use, For instance we can jointly build test base, etc. The teaching resource sharing can also be the student goes to class in other university. Academic credit is a kind of study system by gaining credits to measure the student's task. It is the greatest feature that student can complete the course by the way of choosing himself within certain limits. The student can pay the tuition according to the course's credit. Whether the student can graduate is according to their credit completion situation. The mean can achieve that chooses the course according to the credits, pay the tuition according to the credits and graduate according to the credits. The credit system make the student can choose classes according to their own specialties to other university. They can choose the course that hasn't in his school or higher quality of courses in other university. This can achieve the course sharing by choosing courses each other. The credit system is a study system that is in favor of the teaching resource sharing.

TABLE I. FUNCTION OF ORGANIZATION

\begin{tabular}{|c|c|}
\hline Name of Organization & Function of Organization \\
\hline $\begin{array}{l}\text { University Rectors' } \\
\text { Conference of Higher } \\
\text { Education Park }\end{array}$ & $\begin{array}{l}\text { Develop policies, guidelines, } \\
\text { coordination of major issues }\end{array}$ \\
\hline $\begin{array}{l}\text { University } \\
\text { Conference of } \\
\text { Education Park }\end{array}$ & $\begin{array}{l}\text { Coordination of teaching resources } \\
\text { sharing }\end{array}$ \\
\hline $\begin{array}{l}\text { Teaching Steering } \\
\text { Committee of Higher } \\
\text { Education Park }\end{array}$ & Teaching evaluation \\
\hline $\begin{array}{l}\text { Teaching administration } \\
\text { of Higher Education Park }\end{array}$ & Teaching management \\
\hline
\end{tabular}

B. Establish Three-dimensional Structure of

Multi-faceted Teaching Resources Sharing

The course sharing is the best reflects for the teaching resource. Some structures of courses constitute some professional systems. Because there are different levels, different categories and every university has its different characteristics in Higher Education Park. Every university has different advantages in the teaching resource, the subject, professional and the course merit. Therefore a single, independent course sharing should go towards the professional extent and depth. On the basis of choosing courses each other and approving credits, we should establish choosing courses between universities, double professional, double degree, to achieve courses sharing from time to face. We should allow students of the junior university to enter the undergraduate university by choosing courses of the undergraduate university. We should permit the student who is a low level university for the prep school. Let them to read at higher school curriculum. When he is qualified and later admitted to achieve the course sharing from the horizontal to the vertical and establish a solid structure of the teaching resource.

\section{Establish Security System of Teaching Resource Sharing}

The teaching resource sharing in the Higher Education Park is in favor of the advantage complementary between universities, improving the quality of personnel training, improving the utilization of the education resources. Therefore it can improve the teaching efficiency. But resource sharing does not mean to break the boundaries of universities. The Higher Education Park is different from a university. Because of the different school principals, different levels, different characteristics, different advantages in Higher Education Park, the management 
policies and models are different in Higher Education Park.

Firstly, we should establish the identity of the course sharing and management system for instance university A chooses the university B's courses, university A can prescribe the condition of choosing the other university' courses.

Required course_-according to the higher principle to choose other university required course.

Optional course-free or prescribing the maximum credits in other university. University B can provide the course name, the condition of the course section, limiting the number of students for other university. We can implement the first course section for own students, we place the course name on the internet for choosing. Students can choose courses from the internet and feed back in some time. We can charge by credits principle. The university can deduct automatically the charge from the student's campus card according to the credits of his course section and feed back the bill and the subject to students. The charging standard is according to university of setting courses.

Secondly, university should establish an open network for the teaching resources and establish the LAN in Higher Education Park. University information can be input to the information system. Teachers and students can know the resource situation by the information system to choose further. It can achieve step by step on the internet for choosing classes, issuing the teaching information, setting the internet course, answering questions and counseling by the internet. We should fuse fully the LAN to achieve the maximization of teaching resources. Finally we should to establish the monitoring and security system of the teaching process. To establish gradually the monitoring system and improve gradually the teaching quality, by the mean of the student information system, teaching check, etc.

\section{PRINCIPLE OF DESIGNING TEACHING RESOURCES SHARING}

By using the advantage of many universities and operating efficiently of the educational resources system, the goal of constructing planning the Higher Education Park is to train more and better talent, to product more and better thinking, to get more and better research results. The basic is to form the good educate people environment and train great teachers and a large number of high-quality creative talent. So we should set the principles of educate people first in the process of the sharing system. The construction and development of the Higher Education Park require the government, university, market integration. If we want it is possible to the combination of three. The government is willing to support the Higher Education Park on the policy, land and financial, train high-quality talent of local, promote the economic and social development of local, by the design of the educational resource sharing system. The school in Higher Education Park is in favor of the school development and increasing the efficiency. Domestic and international enterprise invest can gain larger interests if the invest in the Higher Education Park. So we can set the benefit principle in the sharing system. The benefit principle is the driving that the Higher Education Park construct successfully and develop sustainably.

\section{CONCLUSIONS}

By the construction of the Higher Education Park, we can strengthen the joint among university to achieve the complementary advantages and the resource sharing. Further it forms the running mode that university is in the same condition help each other, commensalism and win-win. In order to avoid Higher Education Park to be a huge university, university has its own characteristics. "Characteristics" is the basic that university can develop in the Higher Education Park. The characteristic is also the sharing premise for other universities.

This research was supported by Science and Technology Project of Henan Science and Technology Office(NO.152102210027) and project of the Education Department of Henan Province (No. 15A520054). We would like to thank the referee for his/her careful reading and helpful suggestions.

\section{REFERENCES}

[1] Zhang Hongbo,Li Yushun: Current Situation of Educational Resource Sharing Environment and Sharing Mechanism. China Educational Technology, 2009, (11).

[2] Liu Shiyu: Exploration on resource sharing in experimental equipment in Higher Education Park. Experimental Technology and Management, 2009, 6(11).

[3] LIU Xiaolin, XU Ming: The Incentive Mechanism of Digital Resources Sharing and Protection of Copyright in China Campus. Modern Educational Technology, 2011, 21(2).

[4] Liu Yirong, Peng Yufei: Integrating and Sharing Educational Resources of Our Higher Educational Zone A case study of Jiangsu Province. Academic Exchange,2008, (10).

[5] He Yongqiang and Wang Xuerui, Study on Educational Resources Management System Based on Grid Technology, AISC 2012, V146.

[6] YE Bing-liang, DAI Wenzhan, YANG Weiqi: Study on the Current Situation and Countermeasures of Laboratory Resources Sharing in Higher-Education Zone. Research and Exploration in Laboratory, 2006, 25(11).

[7] Zhang Xichun: Application of Data Mining in Information Resources Construction and Sharing within the Higher Education Zone. Journal of Library Science, 2010,32(12).

[8] Ding Donglan, Resource Sharing and Open Teaching Model,Zhejiang University Press, 2012.

[9] He Yongqiang and Zhang Shunli, Study on Co-allocation Algorithm of Educational Grid Resource, AISC 2012, V146.

[10] Zhang Zhiying, Theory and methods of professional evaluation of higher education, China Social Sciences Press, 2011.

[11] Avkiran,N.k.Investigating technical and scale efficiency of Australian Universities through data envelopment analysis. Socio-Economic Planning Science, 2001(35) 